\title{
Optimization of Biodiesel Production from Jojoba Oil Using Red Sea Coralline limestone as a heterogeneous Catalyst
}

\author{
Taiseer Hassan M., Ahmed A. A. Youssif, Isameldeen Ibrahim H. A.
}

\begin{abstract}
Jojoba oil (Simmondsia chinensis Link Schneider) has potential as an alternative, nonfood feedstock for Biodiesel production. Jojoba seed which obtained from Erkaweit - Sudan was used in biodiesel (JME) production using Coralline limestone rocks as a heterogeneous catalyst. Coralline limestone rocks is a abundant and environme-ntally friendly in the Red Sea area, the main characteristic of this rock is the high content of calcium carbonate ( $\mathrm{CaCO3}$ ), which was transformed into $\mathrm{CaO}$ by calcinations. The transesterification reaction variables; methanol / oil molar ratio, catalyst weight \% and reaction time were fully optimized using response surface methodology (RSM) based on a central composite design (CCD). The catalyst was characterized by X-ray fluorescence (XRF), Fourier-transform infrared spectroscopy (FTIR), scanning electron microscope (SEM) and HPGe gamma spectrometry. Jojoba seeds were investigated for agronomical parameters, the analysis of jojoba seed gives, $45.187 \mathrm{~g}$ weight of 50 seeds, the seeds measurements were $16.256 \mathrm{~mm}$ length, 10.551 breadth and $9.721 \mathrm{~mm}$ thickness, the proximate composition of the seed were 46.711 oil content, 3.486 Moisture, 1.71 Ash, 15.45 Protein and 32.633 Carbohydrates (by diff.). Jojoba oil was also tested for its physiochemical properties including acid value, peroxide value, FFA, flash point, pour point, refractive index, density, viscosity (a) $40{ }^{\circ} \mathrm{C}$, saponification and iodine values. Proximate analysis of extracted oil gives $(0.936 \mathrm{mgKOH} / \mathrm{g}, 2.469 \mathrm{mEq} / \mathrm{kg}, 0.47 \%, 150$ ${ }^{\circ} \mathrm{C},+9{ }^{\circ} \mathrm{C}, 1.464,0.864 \mathrm{~g} / \mathrm{ml}, 22.507 \mathrm{Cst}, 95.011 \mathrm{mgKOH} / \mathrm{g}$ and $84.20 \mathrm{I} / \mathrm{100g}$ ) respectively. The important fuel properties of Jojoba oil methyl ester (JME) were evaluated including kinematic viscosity @ $40{ }^{\circ} \mathrm{C}(6.783 \mathrm{Cst})$, acid value (034 $\mathrm{mgKOH} / \mathrm{g})$, Flash point $\left(154^{\circ} \mathrm{C}\right)$, density $(865 \mathrm{~kg} / \mathrm{m3})$ and cetane number $(53.33 \mathrm{~min}$.). The fatty acids profile fatty jojoba oil and jojoba methyl ester were established by GC analysis. According to this study, the maximum yield of JME was $81.93 \%$ at $12 / 1$ methanol/oil molar ratio $5 \%$ catalyst weight and 3 hours reaction time.
\end{abstract}

Index Terms - Jojoba seeds, Biodiesel, JME, coralline limestone rock, $\mathrm{CaO}$ catalyst.

\section{INTRODUCTION}

The world is currently challenged with global warming, depletion of non-renewable fossil fuel and environmental pollution [1], due to rapid population and industrialization growth globally [2]. Increase in demand for energy and more consciousness about the environment have led to search for an alternative fuel which can supplement or replace fossil fuel

Taiseer Hassan Mod., Department of Applied Chemistry, Red Sea University/ Assistant Professor, Port Sudan, Sudan, Phone/ +249916011965.

Ahmed A. A. Youssif, Master of degree Student, , Red Sea University/ High Studies College/ Customs Lab., Port Sudan, Sudan, +249912921773.

Isameldeen Ibrahim H. A., Assistant professor in faculty of agriculture, Red sea University.
[3]. Biodiesel is an excellent alternative fuel for replace fossil fuel that could produce from renewable sources and it is biodegradable [4], free of sulfur [5], nontoxic [3], environmental friendly and inexpensive [4]. It can be also used either pure or to blend with petroleum diesel in the unmodified diesel engine, and it reduces exhaust pollutants [6].

The availability and sustainability of biodiesel resources will be the limiting factor in the widespread use of biodiesel [7]. The most common way to produce biodiesel is the transesterification of vegetable oils or animal fats with short chain alcohol such as methanol or ethanol to yield the fatty acid alkyl esters (biodiesel) and glycerol [8].

Jojoba (Simmondsia chinensis \{Link.\}Schneider) is a shrub which grows wild in the semi-arid region of the Sonora desert in northern Mexico and the south-western USA [9]. Jojoba is now cultivated in United States, Israel, Mexico, Peru, Australia, India, Egypt, Thailand, South West Africa, Costa Rica, Argentina, Chile and other countries [10].

Sudan was one of the pioneer countries to introduce jojoba in 1974 through a combined work between the U.N Developmental Program and the University of CaliforniaRiverside. Many areas of different climates and soil types such as Arkaweit, Eddamer, Sagelneiam, Bara, Dungla, Elhudeiba and ELrwakib have been selected as experimental sites. The results were very successful and the plant growth exceeded its growth in native areas and proved to be well adapted to Sudan climate [11].

Jojoba seeds contain from 40 to $60 \%$ of oil which is chemically classified as liquid wax because unlike most vegetable seed oils that are composed of triglycerides, jojoba oil consists of esters [12]. The main uses of Jojoba oil-wax are in the cosmetics and pharmaceutical industry, but new uses could arise related to the search of new energetic crops [13].

At chemical level, the jojoba wax consists of extremely long (C36 - C46) straight chain entirely of mono-ethynelic linear fatty acids \& monounsaturated linear fatty alcohol having high molecular weight. Each constituent molecule has 2 double bonds and 1 an ester group in it. Prevailing fatty alcohols and fatty acids are C-20 and C-22 in length [14]. The Jojoba oil-wax has a low chemical reactivity and a very high normal boiling point $\left(398{ }^{\circ} \mathrm{C}\right)$ that gives this product very important physico-chemical properties and uses.

There are basically two types of catalyst that are used in the production of biodiesel namely homogenous and heterogeneous. The term of homogeneous means the catalysts are in the same phase with its reactants, whereas heterogeneous means that the catalysts are in a different phase from its reactant. Further homogenous catalyst can be categorized into homogenous bases and acids [15]. 
Currently, heterogeneous catalysts have been developed for use in a transesterifiation reaction for biodiesel production due to the problems of homogeneous catalysts in terms of water treatment and the nonreusability of the catalyst. Although heterogeneous catalysts have many advantages, their disadvantages are also many such as a high oil-toalcohol molar ratio, high temperature, and a long reaction time [16]. Calcium oxide is one of the most promising heterogeneous base catalysts and it has many advantages such as mild reaction conditions, low cost, high reusability and easy availability [17]. $\mathrm{CaO}$ has attracted many interests as a heterogeneous catalyst because it can be synthesized from cheap sources like calcium carbonate, calcium acetate and calcium nitrate [18].

Coralline limestone (CLR) is a biological sedimentary rocks, composed primarily of calcium carbonate, the exactly mineral composition depend on its origin and the surrounding environment.

The objective of this study is optimisation of biodiesel production from jojoba wax ester using calcined Reds Sea coralline limestone rock as a heterogeneous catalyst.

\section{MATERIALS AND METHODS}

\section{A. Materials}

Jojoba seeds from Erkaweit, Red Sea hills area, 2016 season. Coralline limestone rocks sample obtained from the Dama Dama coast, which produced from the digging and deepening operations in the sea port of Port Sudan.

Chemicals, like n-hexane (Loba Chemie), petroleum ether 40-60 ${ }^{\circ} \mathrm{C}$ (Wagtech), methanol and hydrochloric acid 37\% (Charlo Erba), sodium hydroxide 97-100.5\%,potasium iodide and potassium hydroxide (Scharlau). All chemical reagents were used as purchased with no further purification.

\section{B. Methods}

\section{Catalyst preparations}

Highly active $\mathrm{CaO}$ catalyst was prepared by the calcinations - hydration - dehydration treatment [3]. Coralline limestone rocks were washed with distilled water and then dried in hot air oven at $105^{\circ} \mathrm{C}$ for $24 \mathrm{~h}$. The dried CLR were crushed to small pieces and calcined in a muffle furnace at $900 \mathrm{C}$ for 2.5 hours to transform the calcium carbonate into $\mathrm{CaO}$ particle. Then the $\mathrm{CaO}$ derived from the CLR was refluxed in water at $60 \mathrm{C}$ for 6 hours, filtered and dried in hot air oven at $120 \mathrm{C}$ overnight. The solid product was dehydrated by performing calcination at $600 \mathrm{C}$ for $3 \mathrm{~h}$ to change the hydroxide form to oxide form.

\section{Catalyst Characterization}

The elemental chemical compositions of the material were analyzed by X-ray fluorescence spectroscopy (XRF Oxford). The microstructure of the calcined CLR was observed by Tescan Vega3 XMU scanning electron microscope. Due to the origin of the coralline limestone rock, the radioactivity of the catalyst was studied by HPGe Gamma Spectrometry.

\section{Seed morphology, oil extraction and parameters} seeds were dried in hot air oven at $60{ }^{\circ} \mathrm{C}$ till constant weight achieved. Five samples were drawn from each seed lot and 50 random undamaged seeds (total 250 seeds) were measured for their weight, length, breadth and thickness [19].
Jojoba seeds were ground in porcelain mortar and placed in a Soxhlet extractor for refluxing with $n$-hexane [20]. After 8 hours, the solvent was removed from the extract by heating and evaporating at $80^{\circ} \mathrm{C}$.

The proximate composition of seeds and main physiochemical properties of extracted jojoba oil were evaluated according to the methods described in Pearson's composition and analysis of food [21].

\section{Transesterification reaction}

Reactions were carried out in a $250 \mathrm{ml}$ two-necked round bottom flask. The reactor was initially filled with the desired amount of oil, and then placed in the constant-temperature equipped with reflux condenser, stopper and heated to a predetermined temperature. While $\mathrm{CaO}$ and methanol were mixed and stirred at room temperature $\left(30^{\circ} \mathrm{C}\right)$ for 30 minutes. Then the mixture was added to oil in the reactor and stirred at rate of $750 \mathrm{rpm}$ for the desired time. At the end of the reaction, the product of each part was filtrated into separator funnel to remove the catalyst and allowed to separate overnight. The lower

layer was then evaporated under vacuum in order to get rid of the of the excess methanol. After that the product was washed to eliminate the remaining base catalyst and evaporated the water at $120{ }^{\circ} \mathrm{C}$ for 24 hours [22].

\section{Physicochemical properties of the biodiesel}

The obtained biodiesel have been characterized by some physical measurements: Kinematic viscosity at $40^{\circ} \mathrm{C}$ ASTM D 445, density EN ISO 3675 and EN ISO 12185, flash point, ASTM D 93 and cetane number ASTM D613 and acid value ASTM D664

\section{Fourier transform infrared (FTIR) spectroscopy} FTIR analysis of the catalyst, jojoba oil and produced biodiesel (JME) samples, were carried out using a Shimadzu ir prestige 21 spectrometer. A total of 32 scans were taken from $400-4000 \mathrm{~cm}-1$ with a resolution of $4 \mathrm{~cm}^{-1}$ for each sample.

\section{Gas Chromatography (GC)}

The analysis of FAMEs was performed on a Shimadzu GC-2010 gas chromatograph equipped with flame ionization detector (FID), inertcap FFAP fused silica capillary column $(30 \mathrm{M}, 0.25 \mathrm{~mm}, 0.25 \mu \mathrm{M})$ and split sample inlet system. The gases flow rates were kept as follows: nitrogen as carrier gas $0.5 \mathrm{ml} / \mathrm{min}$, makeup gas nitrogen $30 \mathrm{ml} / \mathrm{min}$, hydrogen 40 $\mathrm{ml} / \mathrm{min}$ and air $400 \mathrm{ml} / \mathrm{min}$ for the detector, sample volume of $1 \mu \mathrm{l}$ was used as injection volume and the split ratio was 1:5, temperature setting were as follows; injector $260 \mathrm{C}^{\circ}$ detector $270 \mathrm{C}^{\circ}$, and the oven temperature was programmed as follow; intial temp. Was $140 \mathrm{C}^{\circ}$ at which it was held for $3 \mathrm{~min}$ and increased at $5 \mathrm{C}^{\circ} / \mathrm{min}$ until $160 \mathrm{C}^{\circ}$ and held for $5 \mathrm{~min}$ and increased at $5 \mathrm{C}^{\circ} / \mathrm{min}$ until $240 \mathrm{C}^{\circ}$ and finally which was held for $12 \mathrm{~min}$., a total of $40 \mathrm{~min}$. Was necessary to assay the FAMEs. The peak areas were normalised \& integrated with SHIMADZU GCsolution chromatography data system version 2.3 .

FAMEs were prepaired according to method described by wang et al 2015 [23]. $40 \mu \mathrm{l}$ was placed into $10 \mathrm{ml}$ centrifuge tubes to which $0.7 \mathrm{ml}$ of potassium hydroxide $(10 \mathrm{M})$ solution and $5.3 \mathrm{ml}$ of methanol were added. The reaction was performed at $55^{\circ} \mathrm{C}$ for $1.5 \mathrm{~h}$ with mixing for $5 \mathrm{~s}$ every $20 \mathrm{~min}$. 
After cooling to room temperature, $3 \mathrm{ml}$ of $\mathrm{n}$-hexane was added and mixed for $5 \mathrm{~min}$. Subsequently, the tubes were centrifuged for $5 \mathrm{~min}$. And the extracts were removed for GC. FAMEs were identified by comparing the retention times of the unknown components with a known FAMEs standard mixture which was injected under the same instrument condition and quantified by comparing their peak areas of the FAMEs standard mixture.

\section{Experimental design}

Statistical experimental design forms an essential part of any laboratory work as it limits the number of time consuming experiments and also ensures that most suitable data can be obtained from minimum experimental work [24]. The experimental design selected for this study is Central Composite Design (CCD) and the response measured which is the dependent variable is the yield of biodiesel.

In order to optimize the process variables for biodiesel production from jojoba oil transesterification, examine the combined effect of the three different independent variables; methanol to oil ratio, reaction time, catalyst weight on yield and derive a model, five levels, four factors central composite factorial design (CCD) which includes 14 factorial points plus 6 central points leading to a total of 20 experiments (Table 1) were adopted in this study. Variables investigated were chosen by considering the preliminary tests on effect of individual variables on biodiesel yield and operating limits of the biodiesel production process conditions [25].

The obtained experimental data was analyzed using a second-order polynomial (see (1)) to find the relationship between the independent variables and the \% FAME conversion [16]

$Y_{i}=\beta_{0}+\sum_{i=1}^{k} \beta_{i} X_{i}+\sum_{i=1}^{k} \beta_{i i} X i^{2}+\sum_{i=1}^{k} \sum_{j=1}^{k} \beta_{i} X_{i} X_{j}$

Where $Y$ is the response factor (fatty acid methyl ester contents), $X_{i}=$ the Ith term of independent factor, $\beta_{o}=$ intercept, $\beta_{i}=$ linear model coefficient, $\beta_{i i}=$ quadratic coefficient for the factor $i$, and $\beta_{i j}=$ linear model coefficient for the interaction between factors $i$ and $j$.

Table 1. Independent variables and their levels for central composite design of the jojoba oil transesterification.

\begin{tabular}{|c|c|c|c|c|c|c|c|}
\hline \multirow{2}{*}{ Variables } & \multirow{2}{*}{ Units } & \multirow{2}{*}{ Symbols } & \multicolumn{5}{|c|}{ Range and levels } \\
\cline { 4 - 8 } & & -Alpha & Low & 0 & High & +Alpha \\
\hline Methanol/JWE & $\begin{array}{c}\text { Molar } \\
\text { ratio }\end{array}$ & $\mathrm{A}(\mathrm{X} 1)$ & 11.0518 & 12 & 15 & 18 & 18.9482 \\
\hline $\begin{array}{c}\text { Catalyst } \\
\text { Weight }\end{array}$ & $\%$ & $\mathrm{~B}(\mathrm{X} 2)$ & 4.20981 & 5 & 7.5 & 10 & 10.7902 \\
\hline Reaction Time & Hours & $\mathrm{C}(\mathrm{X} 3)$ & 2.68393 & 3 & 4 & 5 & 5.31607 \\
\hline
\end{tabular}

\section{RESULTS AND DISCUSSION}

\section{A. Characterisation of jojoba seed and oil}

The proximate composition of jojoba seeds obtained from Arkaweit was shown in Table 2. Jojob seed contains; 3.486 moisture, 46.711 lipids, 15.45 protein, 1.71 ash and 32.633 carbohydrates (by difference). The agronomical parameters of the seeds were; $45.187 \mathrm{~g}$ Weight of 50 seeds, $16.256 \mathrm{~mm}$, $10.551 \mathrm{~mm}$ and 9.721 for the seeds Length, Breadth and Thickness respectively.
The Physiochemical properties are the most important criteria to check the quality of oils. The physiochemical properties were evaluated and the result obtained is shown in the Table 3. Agarwal et al 2015 [19] reported that the biochemical characteristics of jojoba oil, which were obtained from jojoba seeds having different origin were quite variable and mainly dependent on their geographical origin.

\section{B. Characterisation of Catalyst}

The chemical compositions of the catalyst were characterized by XRF technique. The major mineralogical component is $\mathrm{CaO}$. Calcined CLR had concentration of $97.793 \% \mathrm{CaO}, 1.194 \% \mathrm{SrO}, 0.638 \% \mathrm{~K}_{2} \mathrm{O}, 0.201 \% \mathrm{BaO}$ and $0.109 \% \mathrm{Fe}_{2} \mathrm{O}_{3}$.

The morphology of the obtained $\mathrm{CaO}$ was probed by SEM as shown in Fig. 1. The particles were rough and crack with high porosity. Because, the heat burning effected to organic compounds [4], and results in increasing surface area of catalyst pores and whitened catalyst colour [26].

Table 2. Physicochemical and agronomical parameters of jojoba seeds

\begin{tabular}{|l|l|l|}
\hline Parameter & Unit & Result \\
\hline Weight of 50 seeds & $\mathrm{g}$ & 45.187 \\
\hline Seed Length & $\mathrm{mm}$ & 16.256 \\
\hline Seed Breadth & $\mathrm{mm}$ & 10.551 \\
\hline Seed Thickness & $\mathrm{mm}$ & 9.721 \\
\hline Oil contents & $\%$ & 46.711 \\
\hline Moisture & $\%$ & 3.486 \\
\hline Ash & $\%$ & 1.71 \\
\hline Protein & $\%$ & 15.45 \\
\hline Carbohydrates (by diff.) & $\%$ & 32.633 \\
\hline
\end{tabular}

Table 3. Physiochemical parameters of jojoba oil

\begin{tabular}{|l|l|l|l|}
\hline Parameter & Test method & Unit & Result \\
\hline $\begin{array}{l}\text { Refractive index } \\
\text { at } 25^{\circ} \mathrm{C}\end{array}$ & Pearson`s & & 1.464 \\
\hline Density at $15^{\circ} \mathrm{C}$ & ASTM D 4052 & $\mathrm{g} / \mathrm{ml}$ & 0.864 \\
\hline Viscosity at $40^{\circ} \mathrm{C}$ & ASTM D 7042 & $\mathrm{Cst}$ & 22.507 \\
\hline $\begin{array}{l}\text { Viscosity at } 100 \\
{ }^{\circ} \mathrm{C}\end{array}$ & ASTM D 7042 & $\mathrm{Cst}$ & 6.1637 \\
\hline $\begin{array}{l}\text { Viscosity Index } \\
\text { Flash point }\end{array}$ & ASTM D 7042 & - & 247.9 \\
\hline Pour point & ASTM D 5950 & Deg C & +9 \\
\hline Acid value & Pearson`s & $\mathrm{mgKOH} / \mathrm{g}$ & 0.936 \\
\hline FFA & Pearson`s & $\%$ & 0.47 \\
\hline Peroxide value & Pearson`s & $\mathrm{mEq} / \mathrm{kg}$ & 2.469 \\
\hline $\begin{array}{l}\text { Saponification } \\
\text { Value }\end{array}$ & Pearson`s & $\mathrm{mgKOH} / \mathrm{g}$ & 95.011 \\
\hline Iodine Value & Pearson`s & $\mathrm{I}_{2} / 100 \mathrm{~g}$ & 84.20 \\
\hline
\end{tabular}




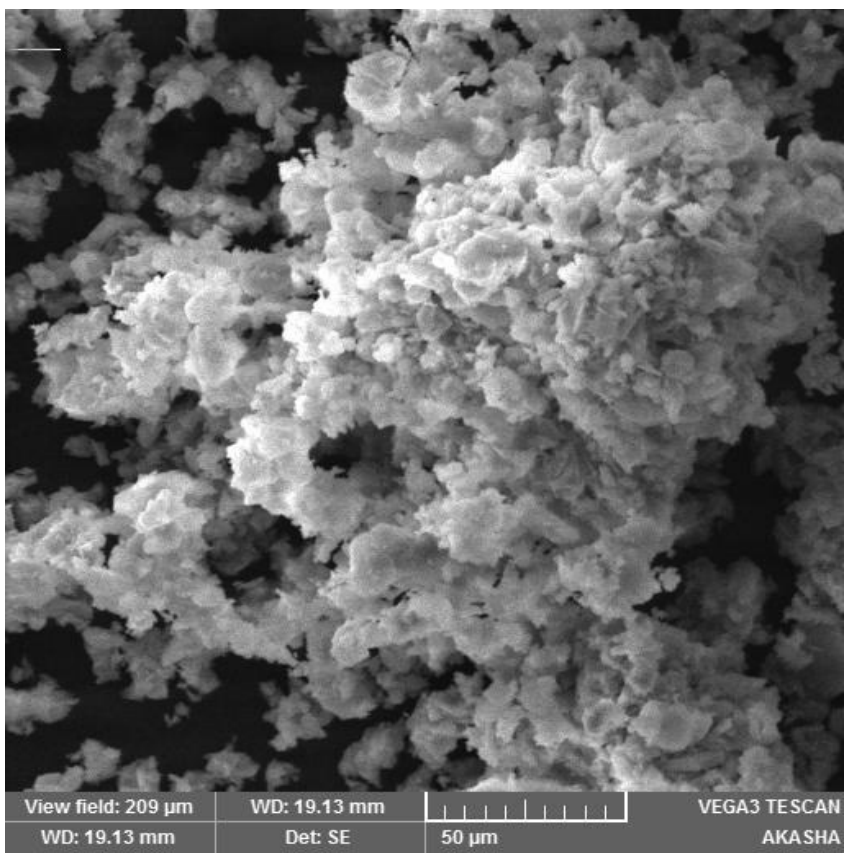

Figure 1. SEM analysis of $\mathrm{CaO}$ catalyst

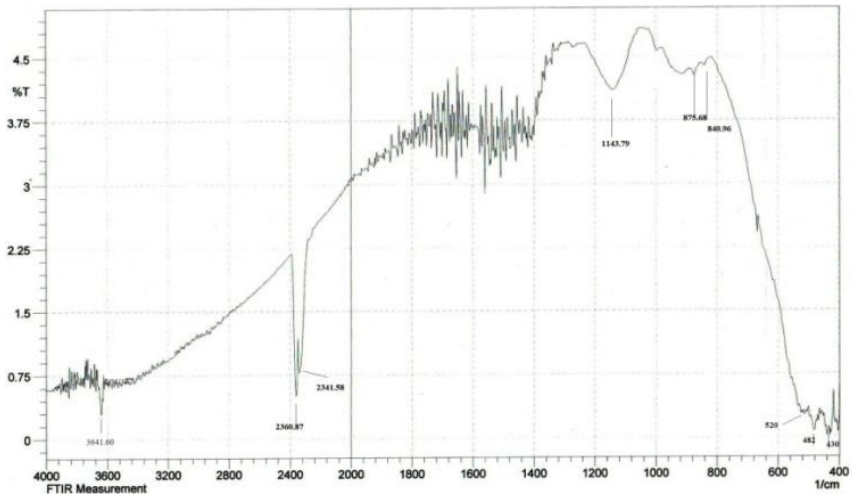

Figure 2. IR spectrum of calcium oxide from decomposition of coralline limestone rocks.

The FTIR spectra of $\mathrm{CaO}$ catalyst derived from calcined CLR shown in Fig. 2. The broad band at $\sim 1621 \mathrm{~cm}^{-1}$ and sharp band at $3641 \mathrm{~cm}^{-1}$ areassociated with $\mathrm{OH}$ stretching vibration mode of water physisorbed on the surface of the $\mathrm{CaO}$ [27], calcium oxide can absorb water vapor from the air easily [26]. The weak band at $875.68 \mathrm{~cm}^{-1}$ shows the presence of $\mathrm{Ca}-\mathrm{O}$ bond [28],[29].

Gamma spectrometry analysis of the coralline limestone rock was performed with a computer-based gamma spectrometry system for qualitative and quantitative determination of gamma-emitting radionuclides.

The results displayed in table 4 and Fig. 3 shows that the obtained activity of ${ }^{238} \mathrm{U}$ concentration activity is $65(\mathrm{~Bq} / \mathrm{kg})$ and ${ }^{226} \mathrm{Ra}$ concentration activity is $56.6(\mathrm{~Bq} / \mathrm{kg})$, this values fall within the range of corresponding values published for other locations in the world [30].

\section{Physicochemical properties of Jojoba biodiesel (JME)}

The physiochemical properties of jojoba methyl ester were measured under corresponding ASTM standards. Some of important fuel properties of the jojoba biodiesel are presented in Table 5 . The density at $15{ }^{\circ} \mathrm{C}$ was found to be $865 \mathrm{~kg} / \mathrm{m}^{3}$ which is in the acceptable limits of standards. The kinematic viscosity was found $6.783 \mathrm{~mm}^{2} / \mathrm{s}$ which is slightly higher than the ASTM standards, due to high fatty acid composition [31],
[32]. The flash point, acid value and cetane number of JME were $154{ }^{\circ} \mathrm{C}, 0.34 \mathrm{mgKOH} / \mathrm{g}$ and $53.33 \mathrm{~min}$. respectively.

Table 4. Radioactivity of coralline limestone rock

\begin{tabular}{|c|c|c|c|c|}
\hline $\begin{array}{c}\text { Nuclides/ } \\
\text { Lines }\end{array}$ & $\begin{array}{c}\text { Area } \\
\text { [impulse] }\end{array}$ & $\begin{array}{c}\text { Activity, } \\
\text { Bq/kg }\end{array}$ & $\begin{array}{c}\text { Relative } \\
\text { uncertinity, } \\
\%\end{array}$ & $\begin{array}{c}\text { MDA, } \\
\text { Bq }\end{array}$ \\
\hline U-238 & 311 & 65 & 14 & 26.97 \\
\hline Ra-226 & 5190 & 56.6 & 1.9 & 0.5 \\
\hline
\end{tabular}

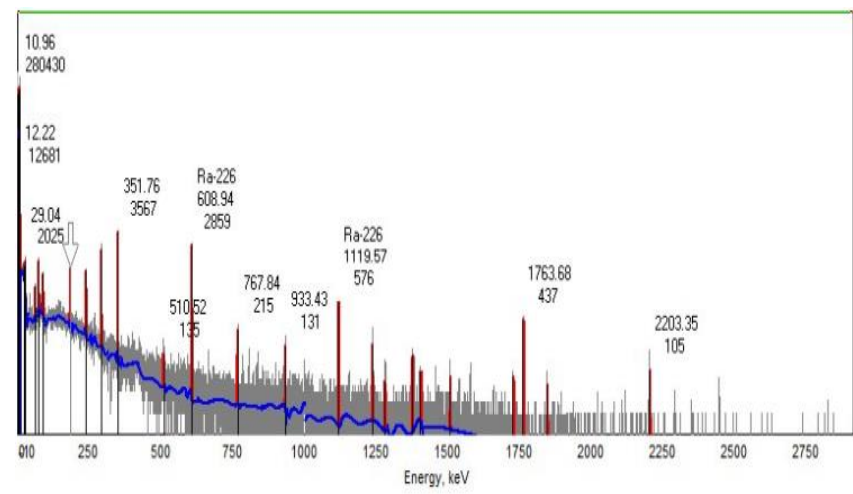

Figure 3. Gamma spectrum of coralline lime stone rock.

Table 5. Physicochemical properties of JME.

\begin{tabular}{|l|l|l|l|l|}
\hline Parameter & $\begin{array}{l}\text { Test } \\
\text { Method }\end{array}$ & Unit & JME & $\begin{array}{l}\text { ASTM } \\
\text { D6751-07b }\end{array}$ \\
\hline $\begin{array}{l}\text { Kinematic Viscosity } \\
\text { at } 40^{\circ} \mathrm{C}\end{array}$ & $\begin{array}{l}\text { ASTM D } \\
445\end{array}$ & Cst & 6.78 & $1.9-6.0$ \\
\hline Flash Point & $\begin{array}{l}\text { ASTM D } \\
93\end{array}$ & $\begin{array}{l}\text { Deg } \\
\text { C }\end{array}$ & 154 & $130 \mathrm{~min}$ \\
\hline Density & $\begin{array}{l}\text { EN ISO } \\
3675 \\
\text { EN ISO } \\
\text { kg/m }\end{array}$ & & 865 & $860-900$ \\
& 12185 & & & \\
\hline Cetane number & $\begin{array}{l}\text { ASTM D } \\
613\end{array}$ & min. & 53.3 & $47 \mathrm{~min}$ \\
& & & & \\
\hline
\end{tabular}

Table 6. Fatty acid profile of jojoba oil and jojoba methyl ester (JME).

\begin{tabular}{|l|l|l|}
\hline Ester profile & Jojoba oil & JME \\
\hline Lauric acid (C12:0) & 1.05 & 0.98 \\
\hline Palmitic acid (C16:0) & 0.40 & \\
\hline Oleic acid (C18:1) & 6.17 & 9.26 \\
\hline Eicosenoic acid (C20:1) & 69.83 & 53.68 \\
\hline Behenic acidC22:0 & 7.23 & \\
\hline Erucic acid (C22:1) & 13.71 & 15.41 \\
\hline Nervonic acid C24:1 & 1.61 & 2.5 \\
\hline
\end{tabular}

\section{Gas chromatography $(G C)$}

The results, based on GC analyses, of the jojoba seed oil and jojoba methyl ester indicated that the oil contains fatty acids of carbon atoms from C 12 to C 24 (saturated and unsaturated). The main fatty acids constituents (average) of Jojoba seed oil (Table 6) are ecosenoic acid (69.83), erucic acid (13.71), behenic acid (7.23), oleic acid (6.17), Nervonic acid C24:1 (1.61) and Lauric acid (1.05) The fatty acids profile of JME biodiesel (Table 6), showed that methyl-cis-11-eicosenoate, $\mathrm{C} 20: 1$ is the major constituent followed by methyl-cis-13-docosenoate, C 22:1), C18:1 and 24:1 respectively. whereas C12.0 was present at 
low concentration amounted. These results were slightly different from the neighbouring countries [33], [34]. Beside, some studies have shown that the content and composition of jojoba oil is strongly related to the genetic variability of the plant [12].

\section{FT-IR Spectroscopy}

The FT-IR spectrum of jojoba oil (figure 4) indicate that it contains the following peaks; 3462.22, 3005.10, 2925.60, $2854.65,2682.98,1739.79,1654.92,1456.18,1170.79$, 1043.49 and $721.38 \mathrm{~cm}-1$ [35]. The stretching and bending absorption peaks at 3005.10 and $721.38 \mathrm{~cm}-1$ which correspond to olefinic (-CH) group [36]. The spectra also show other stretching absorption bands at 1654.92, 1739.79 and $1170.79 \mathrm{~cm}-1$ which correspond to $(\mathrm{C}=\mathrm{C})$ bond, $\mathrm{C}=\mathrm{O}$ and $\mathrm{C}-\mathrm{O}$ of ester group respectively. The bands of $\mathrm{CH} 3$ and $\mathrm{CH} 2$ groups appear at 2925.60 and $2854.65 \mathrm{~cm}-1$ [36].

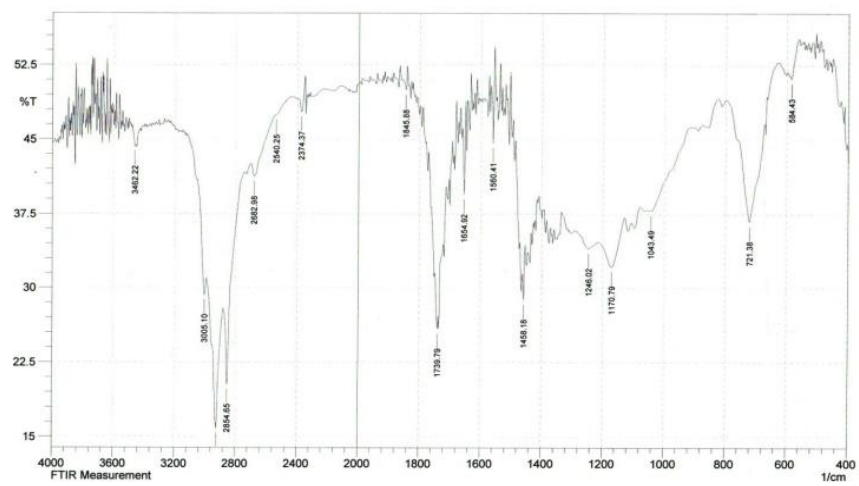

Figure 4. FT-IR spectrum of jojoba oil

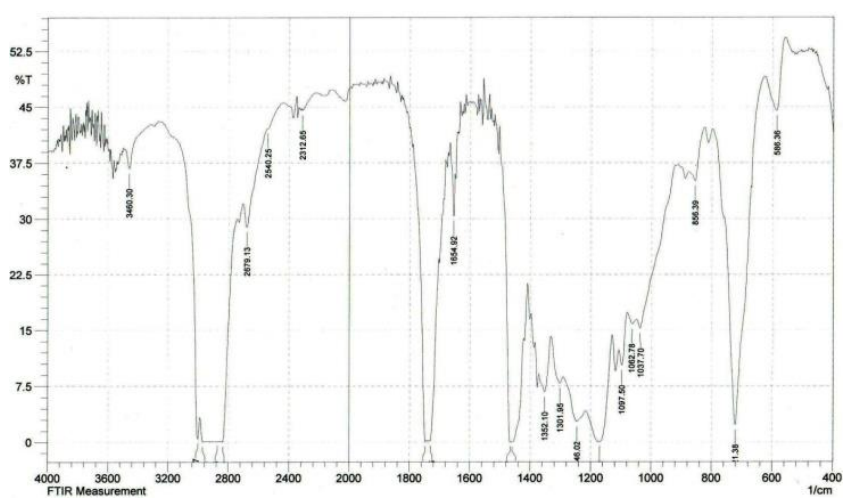

Figure 5. FT-IR spectrum of jojoba methyl ester (JME)

The FT-IR spectrum of jojoba methyl ester (figure 5) indicate that it contains the following peaks; 3460.30, $3008.95,2931.80,2862.38,1749.44,1728.22$, 1654,92, $1469.76,1352.10,1301.95,1246.02,1170.79$ and 721.38 cm-1 [35]. JME seem to be in a purer state due to absence of this wide broad band at $33460.30 \mathrm{~cm}-1$ [37], carbonyl stretching at $1749.44 \mathrm{~cm}-1$ and C-O-C asymmetric stretching at 1170.79 [20]. The band at 1352.10 corresponds to the $-\mathrm{CH} 2$ and $-\mathrm{CH} 3$ flexion vibration [38]. The olefinic chain vibration were; $3008.95 \mathrm{~cm}-1$ vinylic $\mathrm{C}-\mathrm{H}$ stretching, 2931.80 cm-1 aliphatic C-H stretching and $1469.76 \mathrm{~cm}-1 \mathrm{C}-\mathrm{H}$ in-plane bending [20], and the band at $1654.92 \mathrm{~cm}-1$ due to the double bond [37]. Which is not conjugate with the carbonyl group [20].

\section{Optimization of Reaction Conditions}

RSM was employed to evaluate the relations between the response (\% JME conversion) and the three reaction variables. The coded and uncoded independent variables for reaction experiment parameter were designed as shown in Table 7. 20 experiments were performed in a randomized order. The response obtained from the regression analysis was correlated with the three independent variables using second-order polynomial equation.

The JME\% conversion obtained at the design points of different reaction conditions is shown in Table 7. The observed values varied between $70.45 \%$ at $15 / 1$ methanol/oil molar ratio $10.7902 \%$ catalyst weight and 4 hours reaction time, and $81.93 \%$ at 12/1 methanol/oil molar ratio 5\% catalyst weight and 3 hours reaction time.

The Design-Expert software was used to determine and evaluate the coefficients of the full regression model equation and their statistical significance. The quadratic regression model used to predict the \% JME conversion is shown in eq. 2. [16]

$1 /(\mathrm{JME})=+0.014+3.335 \mathrm{E}-004 \mathrm{~A}+1.967 \mathrm{E}-004 \mathrm{~B}$ $+8.726 \mathrm{E}-005-2.328 \mathrm{E}-004 \mathrm{AB}-9.621 \mathrm{E}-005 \mathrm{AC}$ $-7.335 \mathrm{E}-006 \mathrm{BC}-3.946 \mathrm{E}-004 \mathrm{~A}^{2}+2.871 \mathrm{E}-005 \mathrm{~B}^{2}$ $-3.209 \mathrm{E}-004 \mathrm{C}^{2}$

(2)

Where is the response variable of \% JME conversion and $A$, $B$, and $C$ are the actual values of the predicted methanol/oil molar ratio, catalyst concentration and reaction time respectively.

Table 7: Experimental Results for the Central Composite Design

\begin{tabular}{|c|c|c|c|c|c|c|c|c|}
\hline \multirow{2}{*}{1} & \multirow{2}{*}{ Run } & \multicolumn{3}{|c|}{ Original Factors and Levels } & \multicolumn{3}{|c|}{$\begin{array}{l}\text { Coded Factors and } \\
\text { Levels }\end{array}$} & \multirow{2}{*}{$\begin{array}{c}\text { Yield } \\
\mathrm{Y} \\
(\%) \\
\end{array}$} \\
\hline & & A & B & $\mathrm{C}$ & $\mathrm{X} 1$ & $\mathrm{X} 2$ & $\mathrm{X} 3$ & \\
\hline 11 & 1 & 15 & 4.2098 & 4 & 0 & -1.32 & 0 & 72.87 \\
\hline 18 & 2 & 15 & 7.5 & 4 & 0 & 0 & 0 & 71.91 \\
\hline 19 & 3 & 15 & 7.5 & 4 & 0 & 0 & 0 & 71.93 \\
\hline 1 & 4 & 12 & 5 & 3 & -1 & -1 & -1 & 81.93 \\
\hline 10 & 5 & 18.948 & 7.5 & 4 & 1.316 & 0 & 0 & 73.18 \\
\hline 7 & 6 & 12 & 10 & 5 & $\overline{-1}$ & 1 & 1 & 74.21 \\
\hline 4 & 7 & 18 & 10 & 3 & 1 & 1 & -1 & 74.14 \\
\hline 3 & 8 & 12 & 10 & 3 & -1 & 1 & -1 & 75.89 \\
\hline 14 & 9 & 15 & 7.5 & 5.3161 & 0 & 0 & 1.316 & 74.49 \\
\hline 6 & 10 & 18 & 5 & 5 & 1 & -1 & 1 & 73.77 \\
\hline 2 & 11 & 18 & 5 & 3 & 1 & -1 & -1 & 73.46 \\
\hline 20 & 12 & 15 & 7.5 & 4 & 0 & 0 & 0 & 71.9 \\
\hline 15 & 13 & 15 & 7.5 & 4 & 0 & 0 & 0 & 72.03 \\
\hline 13 & 14 & 15 & 7.5 & 2.6839 & 0 & 0 & -1.32 & 75.29 \\
\hline 17 & 15 & 15 & 7.5 & 4 & 0 & 0 & 0 & 71.71 \\
\hline 9 & 16 & 11.052 & 7.5 & 4 & -1.32 & 0 & 0 & 78.21 \\
\hline 8 & 17 & 18 & 10 & 5 & 1 & 1 & 1 & 73.71 \\
\hline 5 & 18 & 12 & 5 & 5 & -1 & -1 & 1 & 78.75 \\
\hline 16 & 19 & 15 & 7.5 & 4 & 0 & 0 & 0 & 71.89 \\
\hline 12 & 20 & 15 & 10.79 & 4 & 0 & 1.316 & 0 & 70.45 \\
\hline
\end{tabular}


Analysis of Variance for the Response Surface Model

The results of analysis of variance (ANOVA) for the response surface model are shown in Table 3. The result shows that The Model F-value of 223.06 implies the model is significant. There is only a $0.01 \%$ chance that an F-value this large could occur due to noise. Values of (Prob $>$ F) less than 0.0500 indicate model terms are significant. In this case A, B, $\mathrm{C}, \mathrm{AB}, \mathrm{AC}, \mathrm{A}^{2}, \mathrm{C}^{2}$ are significant model terms. Values greater than 0.1000 indicate the model terms are not significant. If there are many insignificant model terms (not counting those required to support hierarchy), model reduction may improve your model. The (Lack of Fit F-value) of 10.19 implies the Lack of Fit is significant.

Table.8: ANOVA for Response Surface Quadratic model

\begin{tabular}{|l|r|r|r|r|r|r|}
\hline Source & $\begin{array}{r}\text { Sum of } \\
\text { Squares }\end{array}$ & $\mathbf{d f}$ & $\begin{array}{r}\text { Mean } \\
\text { Square }\end{array}$ & $\begin{array}{r}\mathbf{F} \\
\text { Value }\end{array}$ & $\begin{array}{r}\text { p-value } \\
\text { Prob }> \\
\mathbf{F}\end{array}$ & \\
\hline Model & $4.55 \mathrm{E}-06$ & 9 & $5.05 \mathrm{E}-07$ & 223.06 & $<0.0001$ & $\begin{array}{r}\text { signif } \\
\text { icant }\end{array}$ \\
\hline $\begin{array}{l}\text { A-Methano } \\
\text { l/JWE }\end{array}$ & $1.28 E-06$ & 1 & $1.28 E-06$ & 563.29 & $<0.0001$ & \\
\hline $\begin{array}{l}\text { B-Catalyst } \\
\text { wt. }\end{array}$ & $4.44 E-07$ & 1 & $4.44 E-07$ & 195.9 & $<0.0001$ & \\
\hline C-Time & $8.73 E-08$ & 1 & $8.73 E-08$ & 38.56 & 0.0001 & \\
\hline AB & $4.33 E-07$ & 1 & $4.33 E-07$ & 191.45 & $<0.0001$ & \\
\hline AC & $7.41 E-08$ & 1 & $7.41 E-08$ & 32.71 & 0.0002 & \\
\hline BC & $4.30 E-10$ & 1 & $4.30 E-10$ & 0.19 & 0.6721 & \\
\hline$A^{2}$ & $1.09 E-06$ & 1 & $1.09 E-06$ & 479.3 & $<0.0001$ & \\
\hline$B^{2}$ & $5.74 E-09$ & 1 & $5.74 E-09$ & 2.54 & 0.1423 & \\
\hline$C^{2}$ & $7.17 E-07$ & 1 & $7.17 E-07$ & 316.84 & $<0.0001$ & \\
\hline Residual & $2.26 \mathrm{E}-08$ & 10 & $2.26 \mathrm{E}-09$ & & & \\
\hline Lack of Fit & $2.06 E-08$ & 5 & $4.12 E-09$ & 10.19 & 0.0118 & $\begin{array}{r}\text { signif } \\
\text { icant }\end{array}$ \\
\hline Pure Error & $2.02 E-09$ & 5 & $4.05 E-10$ & & & \\
\hline Cor Total & $4.57 \mathrm{E}-06$ & 19 & & & & \\
\hline
\end{tabular}

There is only a $1.18 \%$ chance that a (Lack of Fit F-value) this large could occur due to noise. Significant lack of fit is bad -we want the model to fit

\section{Coefficient of Regression Analysis}

Table 9 contains the result of the coefficient of regression analysis. The Coefficient of determination (R-Squared = 0.9950) shows that the fit of the model is good. The closer the value to unity, the better the empirical model fits the actual data. It implies that $99.50 \%$ of the total variability in the response is explained by the model.

The (Pred R-Squared) of 0.9435 is in reasonable agreement with the (Adj R-Squared) of 0.9906, That is to say the difference is less than 0.2. Which shows high accuracy of the model in predicting the yield of the biodiesel for given factor combination settings [39].

Adeq. Precision measures the signal to noise ratio. A ratio greater than 4 is desirable. This ratio of 57.933 indicates an adequate signal. This model can be used to navigate the design space.

Table 9 Coefficient of Regression Analysis

\begin{tabular}{|l|r|l|r|}
\hline Std. Dev. & $4.758 E-005$ & R-Squared & 0.9950 \\
\hline Mean & 0.014 & Adj R-Squared & 0.9906 \\
\hline C.V. \% & 0.35 & Pred R-Squared & 0.9435 \\
\hline PRESS & $2.579 E-007$ & Adeq Precision & 57.933 \\
\hline -2 Log Likelihood & -355.23 & BIC & -325.27 \\
\hline & & AICc & -310.78 \\
\hline
\end{tabular}

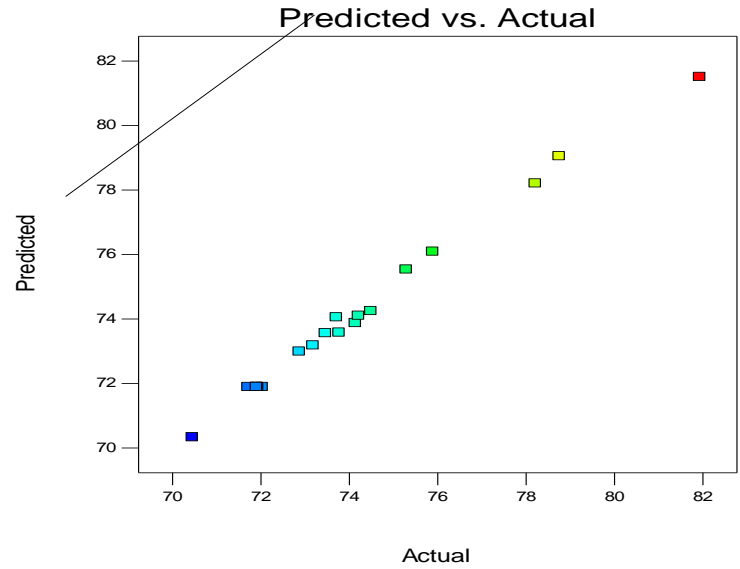

Figure 6. Parity chart for the model employed. Plot of predicted vs. actual value.

Figure 6 represents the actual results obtained from the experiments versus the predicted data by empirical model. The values of the adjusted determination coefficient $\left(\mathrm{R}^{2}\right.$ adj) and the determination coeffient $\left(\mathrm{R}^{2}\right)$ were 0.9906 and 0.9435 , respectively. The high value of both coefficients justifies an excellent correlation between the independent variables and supports a high significance of the model. Meanwhile, the coefficient of variation was $0.35 \%$. The relatively low value of the coefficient of variation reveals better reliability for this fitted model [16].

\section{Interaction of variables}

The effects of the process variables on the JME conversion were studied by plotting three-dimensional surface curves against any two independent variables while keeping the third variable at their central (0) level [16]. The 3D curves of the response from the effect of independent variables are shown in Figures 7(a)-7(c).

Figure 7(a) illustrates the effect of methanol/oil molar ratio and catalyst weight on \% JME conversion at 4 hours reaction time. The result reveals that the \% JME conversion decreases with increasing catalyst concentration and methanol/oil molar ratio. For the amount of catalyst, there is a significant negative effect on the transesterifiation of jojba oil to JME, due poor mixing of the reaction mixture hence aggregation and dilution of catalysts [1].

Figure 7(b) illustrates the effect of methanol/oil molar ratio and reaction time on \% JME conversion at 7.5 catalyst weight The \% JME conversion increases with increasing reaction time and decrease with increasing methanol/oil molar ratio.

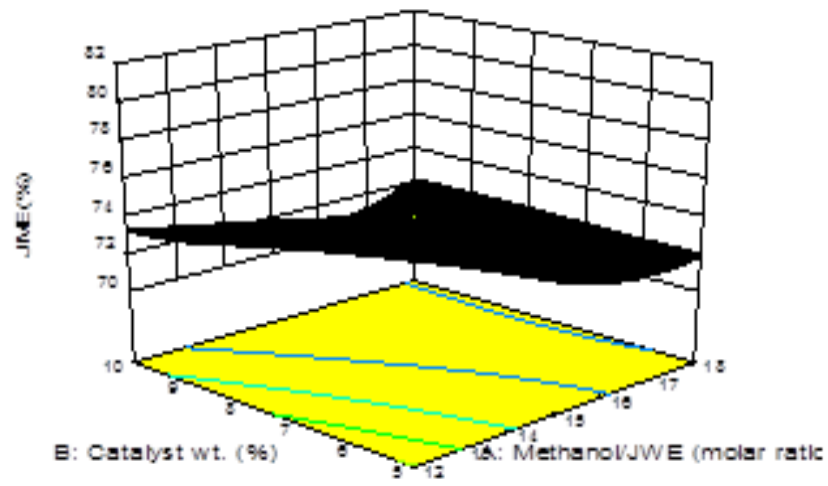

Figure 7(a). The effect of catalyst weight and methanol/oil molar ratio on \% JME conversion at 4 hours reaction time 


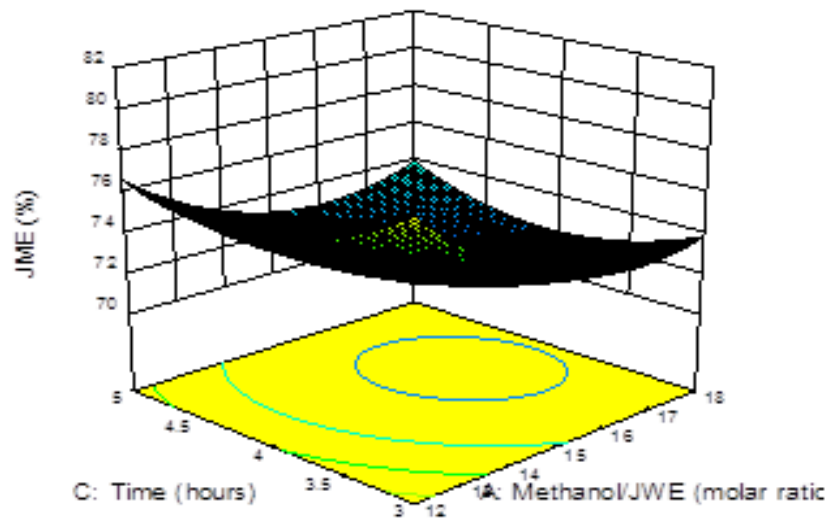

Figure 7(b). Effect of methanol/oil molar ratio and reaction time on $\%$ JME conversion at 7.5 catalyst weight

Figure 7(c) illustrates the effect of catalyst weight and reaction time on \% JME conversion at 15:1 methanol/oil molar ratio. The \% JME conversion increases when catalyst weight decrease and reaction time increase.

Then, there is a slight decrease when the reaction period is too long due to the influence of the reversible reaction in transesterification [16]. Too long reaction time resulted in the appearance of a white gel in the product, which increased the viscosity of the product and affected the purification process [40].

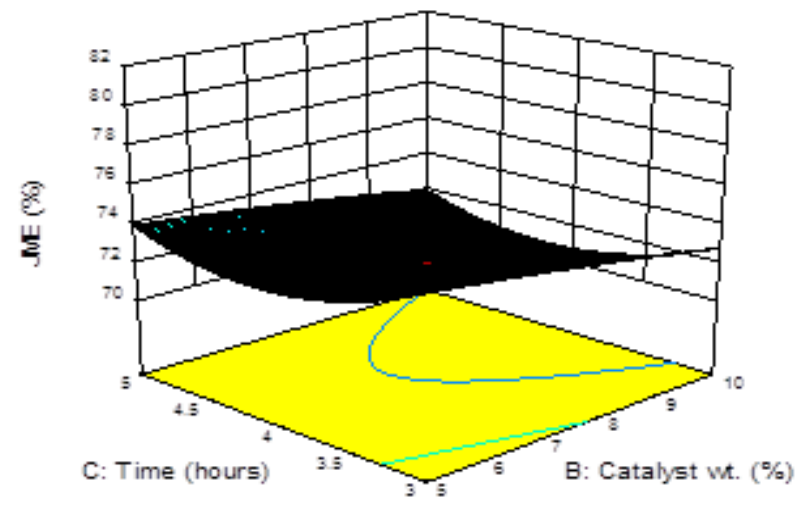

Figure 7(c). Effect of catalyst weight and reaction time on $\%$ JME conversion at 15:1 methanol/oil molar ratio.

\section{CONCLUSION}

RSM was applied to the transesterifiation reaction between jojoba oil and methanol using a $\mathrm{CaO}$ as a heterogeneous catalyst. Experimental conditions such as methanol/oil molar ratio, catalyst weight and reaction time, were evaluated and optimal conditions for achieving the higher yields were evaluated The calcined corallined limestone rocks (catalyst) was characterized by The SEM, FTIR and HPGe gamma spectrometry. The catalyst showed excellent performance in biodiesel production.

The feedstock and produced biodiesel were characterized by FTIR and GC techniques. The physical, chemical and fuel properties of biodiesel were conformed to EN/ASTM standards.

\section{ACKNOWLEDGMENTS}

The authors gratefully acknowledge Abdu Al-atheem, Rehab and Saif El-Dien for their helping in analysis.

\section{REFERENCES}

N. Tshizanga, E. F. Aransiola, and O. Oyekola, "Optimisation of biodiesel production from waste vegetable oil and eggshell ash," South African J. Chem. Eng., vol. 23, pp. 145-156, 2017.

M. K. Lam, K. T. Lee, and A. R. Mohamed, "Homogeneous, heterogeneous and enzymatic catalysis for transesterification of high free fatty acid oil (waste cooking oil) to biodiesel: A review," Biotechnol. Adv., vol. 28, no. 4, pp. 500-518, 2010.

S. Niju, M. M. M. S. Begum, and N. Anantharaman, "Modification of egg shell and its application in biodiesel production," J. Saudi Chem. Soc., vol. 18, no. 5, pp. 702-706, 2014.

S. Kaewdaeng, P. Sintuya, and R. Nirunsin, "Biodiesel production using calcium oxide from river snail shell ash as catalyst," Energy Procedia, vol. 138, pp. 937-942, 2017.

F. A. Zaher and H. M. Soliman, "Biodiesel production by direct esterification of fatty acids with propyl and butyl alcohols," Egypt. J. Pet., vol. 24, no. 4, pp. 439-443, 2015.

D. N. Thoai, S. Photaworn, A. Kumar, K. Prasertsit, and C. Tongurai, "A Novel Chemical Method for Determining Ester Content in Biodiesel," Energy Procedia, vol. 138, pp. 536-543, 2017.

R. a Taha, "Biofuel Promising Plants and Micropropagation," Adv. Plants Agric. Res., vol. 4, no. 6, pp. 394-395, 2016

Z. Kesic, I. Lukic, M. Zdujic, L. Mojovic, and D. Skala, "Calcium oxide based catalysts for biodiesel production: A review," Chem. Ind. Chem. Eng. Q., vol. 22, no. 4, pp. 391-408, 2016.

P. R. Waiters, N. Macfarlane, and P. C. Spensley, "Jojoba: An assessment of prospects," 1979.

R. S. Andrade, A. D. Andrade, and A. L. A. Simões, "Thermodynamic Study of Jojoba ( Simmondsia Chinensis ) Oil as a Function of Temperature," Int. J. Eng. Res. Technol., vol. 6, no. 02, pp. 245-250, 2017.

T. D. M. Elamin, "JOJOBA (Simmondsia Chinensis) (LINK) SCHNEIDER) SEED GERMINATION AND SEEDLING ESTABLISHMENT UNDER SUDAN CONDITIONS," University of Khartoum, 2006.

N. A. Lizarde, L. A. Meléndez, M. a. A. Escalante, T. R. Granados, P. C. Hernández, and C. L. C. Vázquez, "Physicochemical Composition of Seed Oil of Wild Jojoba Populations in Northwestern Mexico," J. Food Nutr. Res., vol. 5, no. 6, pp. 443-450, 2017.

[13] L. Canoira, R. Alcántara, M. Jesús García-Martínez, and J. Carrasco, "Biodiesel from Jojoba oil-wax: Transesterification with methanol and properties as a fuel," Biomass and Bioenergy, vol. 30, no. 1 , pp. 76-81, 2006.

[14] D. Arya and S. Khan, "A review of simmondsia chinensis (jojoba) 'the desert gold': A multipurpose oil seed crop for industrial uses," J. Pharm. Sci. Res., vol. 8, no. 6, pp. 381-389, 2016.

[15] K. Muthu and T. Viruthagiri, "Optimization and production of biodiesel using calcium oxide as a heterogeneous catalyst," Int. $J$. Chem. Sci., vol. 13, no. 3, pp. 1357-1364, 2015.

[16] N. Chumuang and V. Punsuvon, "Response Surface Methodology for Biodiesel Production Using Calcium Methoxide Catalyst Assisted with Tetrahydrofuran as Cosolvent," J. Chem., vol. 2017, 2017.

[17] S. Niju, K. M. Meera Sheriffa Begum, and N. Anantharaman, "Enhancement of biodiesel synthesis over highly active $\mathrm{CaO}$ derived from natural white bivalve clam shell Enhancement of biodiesel synthesis over highly active CaO," Arab. J. Chem., vol. 9, no. 5, pp. 633-639, 2016.

[18] U. N. Callistus, A. F. Ndidi, O. D. Okechukwu, and A. E. Patric, "5Hdfwlrq .Lqhwlfv Ri \%Lrglhvho 3Urgxfwlrq Iurp 5Hilqhg \&Rwwrqvhhg 2Lo 8Vlqj \&Doflxp 2[Lgh," vol. 10, no. 6, pp. 739-742, 2016.

[19] S. Agarwal, D. Arya, and S. Khan, "Comparative fatty acid and trace elemental analysis identified the best raw material of jojoba (Simmondsia chinensis) for commercial applications," Ann. Agric. Sci., vol. 63, no. 1, pp. 37-45, 2018.

U. M. Dawoud, A. Diş̦í, Y. Yildirir, and B. Z. Uysal, "STRUCTURAL ELUCIDATION OF JOJOBA PLANT (Simmondsia Chinensis) OIL FROM SAUDI ARABIA : SUUDI ARABISTANDA YETIŞEN JOJOBA (Simmondsia Chinensis) BITKKISINDEN ELDE EDILEN YAĞIN YAPISININ AYDINLATMASI," J. Fac. Pharm, Ankara, vol. 31, no. 4, pp. 223-229, 2002. 
[21] R. Kirk, Ronald S; Sawyer, Pearson's Composition and Analysis of Foods, Ninth Edit. Longman Scientific \& Technical, 1991.

[22] K. Prasertsit, P. Phoosakul, and S. Sukmanee, "Use of calcium oxide in palm oil methyl ester production," vol. 63 , no. 2, pp. 159-166, 2012.

[23] J. U. N. Wang, W. Wu, X. Wang, M. I. N. Wang, and F. Wu, “An effective GC method for the determination of the fatty acid composition in silkworm pupae oil using a two-step methylation process," J. Serbian Chem. Soc., vol. 80, no. 1, pp. 9-20, 2015.

[24] R. Naidoo, B. Sithole, and E. Obwaka, "Using response surface methodology in optimisation of biodiesel production via alkali catalysed transesterification of waste cooking oil," J. Sci. Ind. Res. (India)., vol. 75, no. 3, pp. 188-193, 2016.

[25] C. B. Ezekannagha, C. N. Ude, and O. D. Onukwuli, "Optimization of the methanolysis of lard oil in the production of biodiesel with response surface methodology," Egypt. J. Pet., vol. 26, no. 4, pp. 1001-1011, 2017.

[26] N. Widiarti et al., "Catalytic Activity of Calcium Oxide From Fishbone Waste in Waste Cooking Oil Transesterification Process," J. Bahan Alam Terbarukan, vol. 6, no. 2, pp. 97-106, 2017.

[27] Nurhayati, Muhdarina, A. Linggawati, S. Anita, and T. A. Amri, "Preparation and Characterization of Calcium Oxide Heterogeneous Catalyst Derived from Anadara Granosa Shell for Biodiesel Synthesis," KnE Eng., vol. 1, no. 2015, pp. 1-8, 2016.

[28] K. Hasni, a Nabi, M. Varman, and Z. Ilham, "Preparation of Biodiesel from Hibiscus sabdariffa Seeds Oil using Calcium Oxide Catalyst from Waste Egg Shells," J. Soc. Automot. Eng. Malaysia, vol. 2, no. 2, pp. 177-183, 2018.

[29] A. Lesbani, S. O. Ceria Sitompul, R. Mohadi, and N. Hidayati, "Characterization and Utilization of Calcium Oxide $(\mathrm{CaO})$ Thermally Decomposed from Fish Bones as a Catalyst in the Production of Biodiesel from Waste Cooking Oil," Makara J. Technol., vol. 20, no. 3, p. 121, 2016.

[30] A. H. Taqi, A. M. Shaker, and A. A. Battawy, "Natural radioactivity assessment in soil samples from Kirkuk city of Iraq using HPGe detector," Int. J. Radiat. Res., vol. 16, no. 4, 2018.

[31] G. K. Ayetor, A. Sunnu, and J. Parbey, "Effect of biodiesel production parameters on viscosity and yield of methyl esters: Jatropha curcas, Elaeis guineensis and Cocos nucifera," Alexandria Eng. J., vol. 54, no. 4, pp. 1285-1290, 2015.

[32] S. Thirumurugaveerakumar, S. Raghul, S. V. K. S, and R. Ajay, "Production and Property Analysis of Biodiesel from Cotton Seed Oil Using Natural Catalyst," vol. 13, no. 8, pp. 5672-5679, 2018

[33] S. K. AL-Taweel, A. K. G. Atteya, E. A. E. Genaidy, and H. A. Zahran, "Oil Content, Vegetative and Reproductive Traits of Jojoba Plant As Affected By Foliar Application of Gibberellic Acid," IOSR J. Agric. Vet. Sci., vol. 11, no. 2, pp. 53-58, 2018.

[34] A. K. Al-Ghamdi et al., "Study of Jojoba (Simmondsia chinensis) Oil by Gas Chromatography," Nat. Prod. Chem. Res., vol. 05, no. 06, pp. 4-6, 2017.

[35] S. N. Shah, B. K. Sharma, B. R. Moser, and S. Z. Erhan, "Preparation and evaluation of jojoba oil methyl esters as biodiesel and as a blend component in ultra-low sulfur diesel fuel," Bioenergy Res., vol. 3, no. 2, pp. 214-223, 2010.

[36] E. S. H. a. Nashy, M. G. Megahed, and M. a. Abd El-Ghaffar, "Preparation of fat-liquor based on jojoba oil under phase transfer catalysis," JAOCS, J. Am. Oil Chem. Soc., vol. 88, no. 8, pp. 1239-1246, 2011.

[37] L. I. Hussein, M. Z. Elsabee, E. A. Ismail, H. F. Naguib, H. A. Aziz, and M. A. Elsawy, "Transesterification of Jojoba Oil-Wax Using Microwave Technique," Int. J. Chem. Mol. Eng., vol. 8, no. 5, pp. 287-291, 2014.

[38] A. L. LOIS, "Biodiesel and Biokerosenes production and chracterization soot and pah emissions," Madrid University, 2015.

[39] N. C. J., N. M. S., K. F. L., N. a. a., I. P.M.O., and H. I., "Statistical Modeling and Optimization of Biodiesel Production from Azadirachta Indica (Neem) Using Co-Solvent Technique," Int. J. Adv. Eng. Manag. Sci., vol. 4, no. 3, pp. 183-188, 2018.

[40] H. Zhu et al., "Preparation of biodiesel catalyzed by solid super base of calcium oxide and its refining process," Chinese J. Catal., vol. 27, no. 5, pp. 391-396, 2006.
Taiseer Hassan Mohammed, presently working as Assistant professor in Applied Chemistry Department, Red Sea University (RSU). She did her B.E (Chemical Engineering) from RSU and MSc. degree of Engineering from Gadjah Mada University, Indonesia. $\mathrm{PhD}$ in chemical engineering from University of Adelmalek Essaadi. Her research interests are Valorization of Resources, renewable Energy and Environment Protection Technologies.

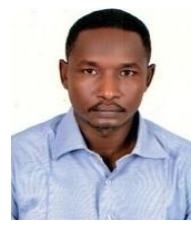

Ahmed Abdalleh Ahmed Youssif, Master of degree student, Faculty of Applied Science, Red Sea University. Work at Customs laboratory - Organic Section. His research interest is application of Lignocellulosic biomass

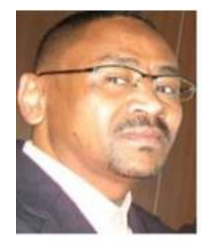

Lsameldeen lbrahim Hassan Abdalleh,Assistant professor ln faculty of agriculture, Red Sea University.sudan 